\title{
A new species and three taxonomic changes in Piper (Piperaceae) from Thailand
}

\author{
C. Suwanphakdee ${ }^{1}$, P. Chantaranothai ${ }^{1}$
}

\author{
Key words \\ Piper \\ Piper chiangdaoense \\ Piper trichostigma \\ synonym \\ Thailand
}

\begin{abstract}
A new species, Piper chiangdaoense from Doi Chiangdao Wildlife Sanctuary, Chiang Mai province, Thailand, is described and illustrated. Piper trichostigma is raised to specific status and an epitype is selected. Piper maculaphyllum and $P$. rubroglandulosum are reduced to the synonymy of $P$. argyrites and $P$. betle, respectively. A lectotype for $P$. argyrites is selected.
\end{abstract}

Published on 13 October 2011

\section{INTRODUCTION}

Piper L. is the largest genus in the family Piperaceae with over a thousand species (Mabberley 2008). Members of the family occur throughout the tropics of both hemispheres, with major concentrations occurring in Latin America and in Malaysia (Yuncker 1958). The genus can easily be recognized on gross morphological characters, but the species are difficult to identify. The flowers are minute and densely set on the rachis, the perianths are absent and the stamens vary in number. The fruits and infructescence are of high importance for species identification.

In preparation of the treatment of Piperaceae for the Flora of Thailand (Office of Forest Herbarium 2010), one new species of Piper, $P$. chiangdaoense, is here described. Two recently described Thai species are reduced to synonymy and a variety is raised to specific rank.

\section{DESCRIPTION OF THE SPECIES}

1. Piper chiangdaoense Suwanp. \& Chantar., sp. nov. - Fig. $1-3$

Affinis Piper lonchites sed foliis cordatis subtus velutinis, inflorescentiis et infructescencetiis brevioribus, fructibus minoribus differt. - Typus: T. Smitinand, M.E.D. Poore \& R.G. Robbins 7806 (holo BKF; iso E), Thailand, Chiang Mai, Doi Chiangdao Wildlife Sanctuary, 10 Nov. 1962.

Woody climber, dioecious, nodes swollen with climbing roots, terminal shoot velutinous. Leaves with petiole $1-1.5 \mathrm{~cm}$ long, velutinous; stipules hood-like, lanceolate, caducous; lamina subcoriaceous, broadly ovate, asymmetric, $2.5-3.5$ by $3.5-4.5$ $\mathrm{cm}$, base cordate or rarely oblique or rounded, apex acute or rarely rounded, margin undulate, upper surface puberulous, lower surface velutinous; venation pinnate with 3 pairs of veins from basal third of midrib. Inflorescence a terminal or leaf-opposed catkin, pendulous, cylindric, yellowish green; rachis hairy, with dense flowers; floral bract glabrous with a c. $0.05 \mathrm{~mm}$ long stalk, bract-head peltate, c. $0.1 \mathrm{~mm}$ diam margin entire. Male inflorescence $3-4$ by $0.1-0.2 \mathrm{~cm}$; peduncle

\footnotetext{
Applied Taxonomic Research Center, Department of Biology, Faculty of Science, Khon Kaen University, Khon Kaen 40002, Thailand; e-mail: PP_SCKU56@yahoo.com.

corresponding author e-mail: pranom@kku.ac.th.
}

Table 1 Comparison of some characters of $P$. lonchites and $P$. chiangdaoense.

\begin{tabular}{|c|c|c|}
\hline Character & P. lonchites & P. chiangdaoense \\
\hline Terminal shoot & glabrous or puberulous & velutinous \\
\hline Lower leaf surface & $\begin{array}{l}\text { glabrous, puberulous or } \\
\text { pilose }\end{array}$ & velutinous \\
\hline Leaf base & $\begin{array}{l}\text { oblique, cuneate, cordate or } \\
\text { truncate }\end{array}$ & $\begin{array}{l}\text { cordate rarely } \\
\text { oblique }\end{array}$ \\
\hline Leaf shape & $\begin{array}{l}\text { elliptic, elliptic-oblong or } \\
\text { ovate }\end{array}$ & broadly ovate \\
\hline Male inflorescence & $2-9 \mathrm{~cm}$ long & $3-4 \mathrm{~cm}$ long \\
\hline Female inflorescence & $3-7 \mathrm{~cm}$ long & $2-4 \mathrm{~cm}$ long \\
\hline Peduncle & glabrous & pilose or velutinous \\
\hline Infructescence & $3-15 \mathrm{~cm}$ long & $3-5 \mathrm{~cm}$ long \\
\hline Fruit & $4-5$ by $3-4 \mathrm{~mm}$ & $2-3$ by $1-2 \mathrm{~mm}$ \\
\hline
\end{tabular}

$1-1.5 \mathrm{~cm}$ long, pilose. Male flower: stamens 4-6; filament very short and basally swollen; anther 2-valved and slightly exserted at anthesis, c. $0.08 \mathrm{~mm}$ diam, dehiscence lateral. Female inflorescence $2-4$ by $0.1-0.2 \mathrm{~cm}$; peduncle $1-2 \mathrm{~cm}$ long. Female flower: ovary \pm elliptic, stigma star-shaped, 3-5-lobed, 1-1.5 $\mathrm{mm}$ diam, hairy. Infructescence $3-5$ by $0.8-1 \mathrm{~cm}$, pendulous, cylindric; peduncle 1-2 cm long. Fruit free, sessile, \pm elliptic, $2-3$ by $1-2 \mathrm{~mm}$, dense or well-spaced on rachis, base rounded, apex acute with persistent stigma and floral bract.

Distribution — Northern Thailand (Doi Chiangdao, Chiangmai).

Habitat \& Ecology — Lower montane forest, at 1500-2175 m altitude.

Phenology — Flowering: May; fruiting: June.

Note - Piper chiangdaoense is similar to $P$. Ionchites Schult. but differs in having a cordate leaf which is velutinous on the lower surface, a shorter inflorescence and a smaller infructescence and fruits. The differences in character are shown in Table 1.

2. Piper trichostigma (Chaveer. \& Sudmoon) Suwanp. \& Chantar., comb. \& stat. nov. - Fig. 1

Piper thomsonii (C.DC.) Hook.f. var. trichostigma Chaveer. \& Sudmoon, Acta Phytotax. Geobot. (2007) 35. - Type: A. Chaveerach 49 (holo BK), Thailand, Mae Hong Son, Mae Sariang; C. Suwanphakdee 259 (epitype $\mathrm{BK}, \mathrm{BKF}, \mathrm{KKU}, \mathrm{QBG}$, here selected), Thailand, Phetchaburi, Kaeng Krachan National Park, 26 Dec. 2008. 


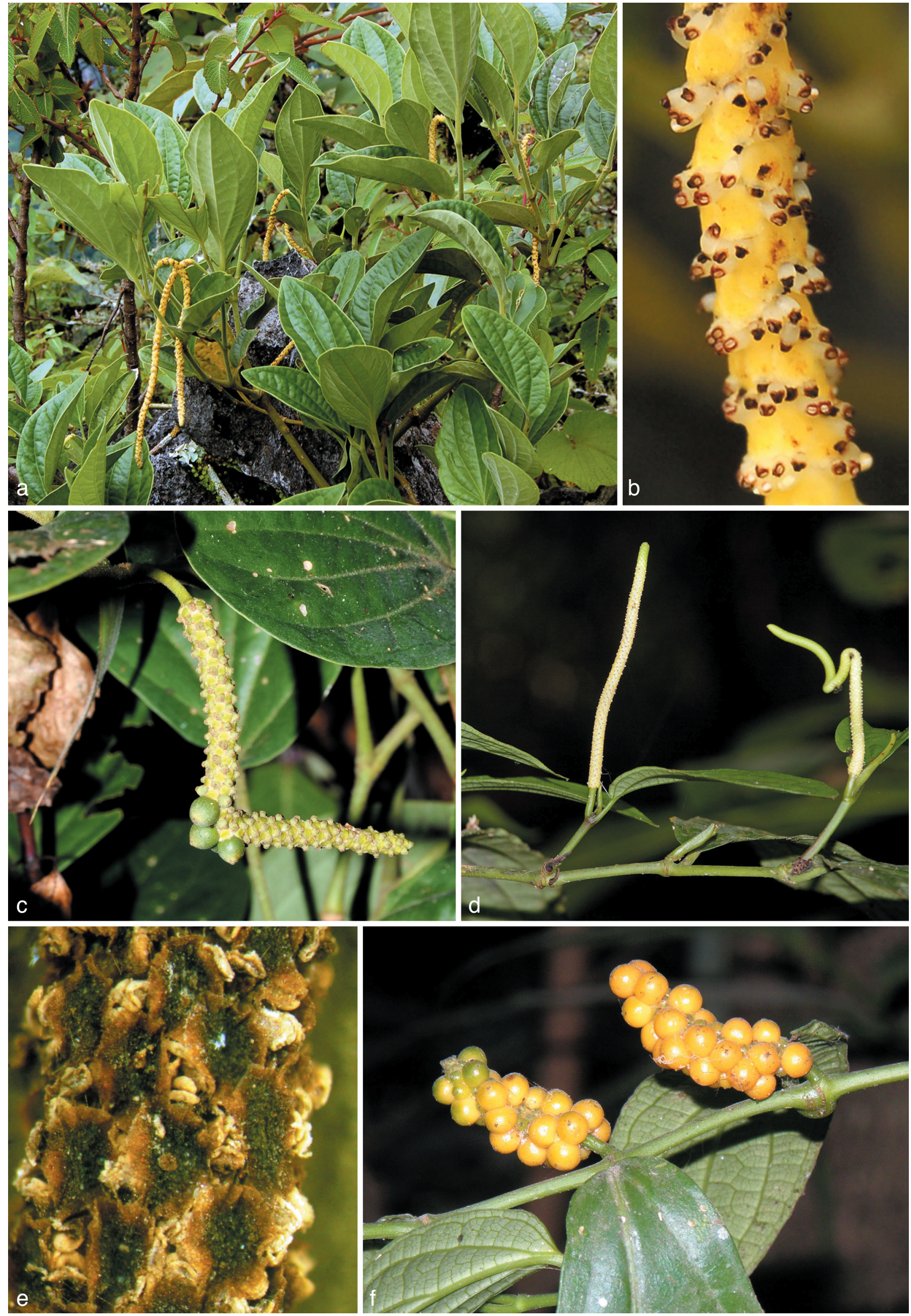

Fig. 1 a-c: Piper chiangdaoense Suwanp. \& Chantar. a. Plant habit; b. portion of male inflorescence; c. infructescence. —d-f: Piper trichostigma (Chaveer. \& Sudmoon) Suwanp. \& Chantar.: d. male inflorescences; e. floral bracts and stamens; f. infructescences. 


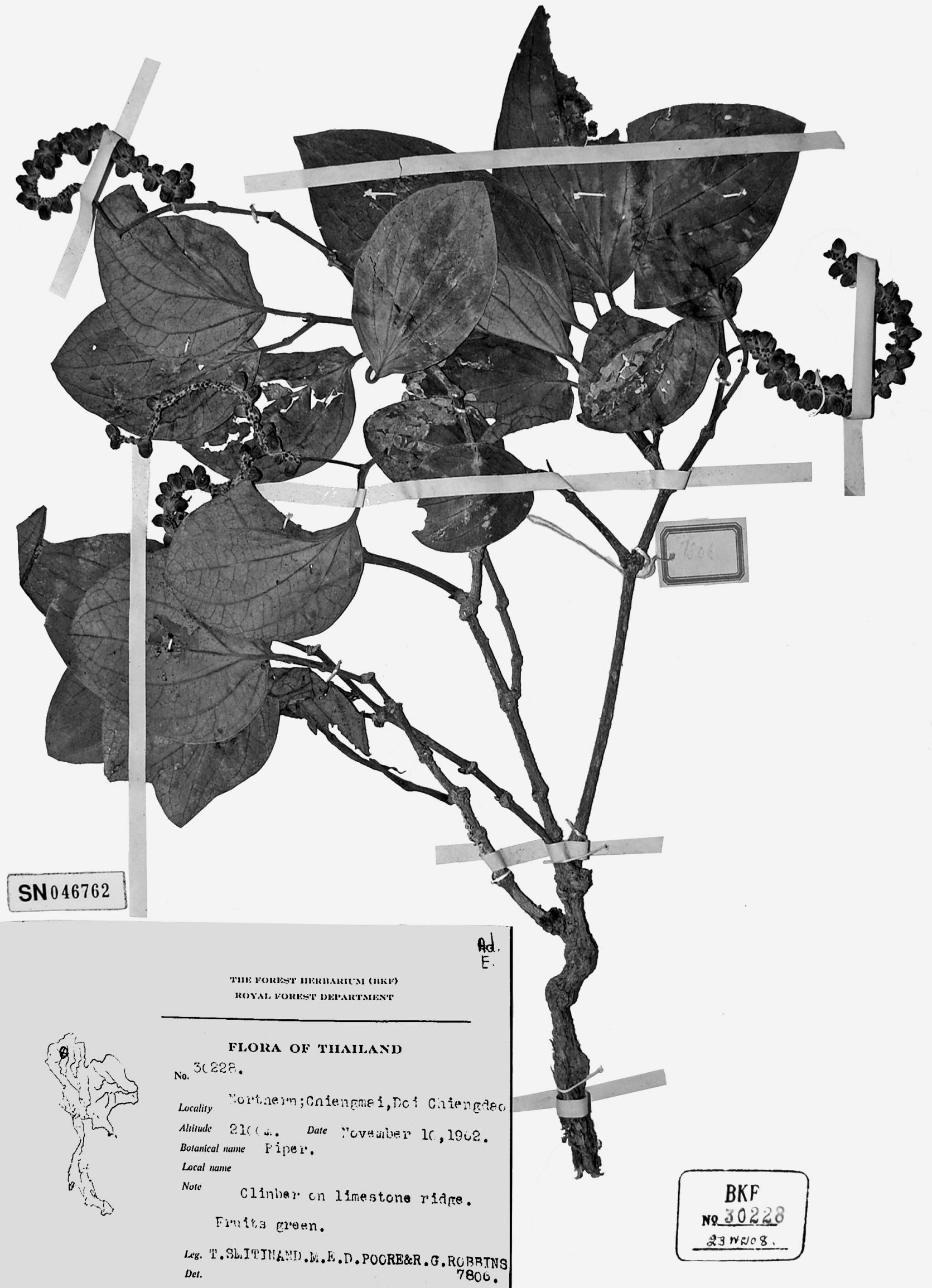

Fig. 2 Type specimen of Piper chiangdaoense Suwanp. \& Chantar. (T. Smitinand et al. 7806, BKF). 


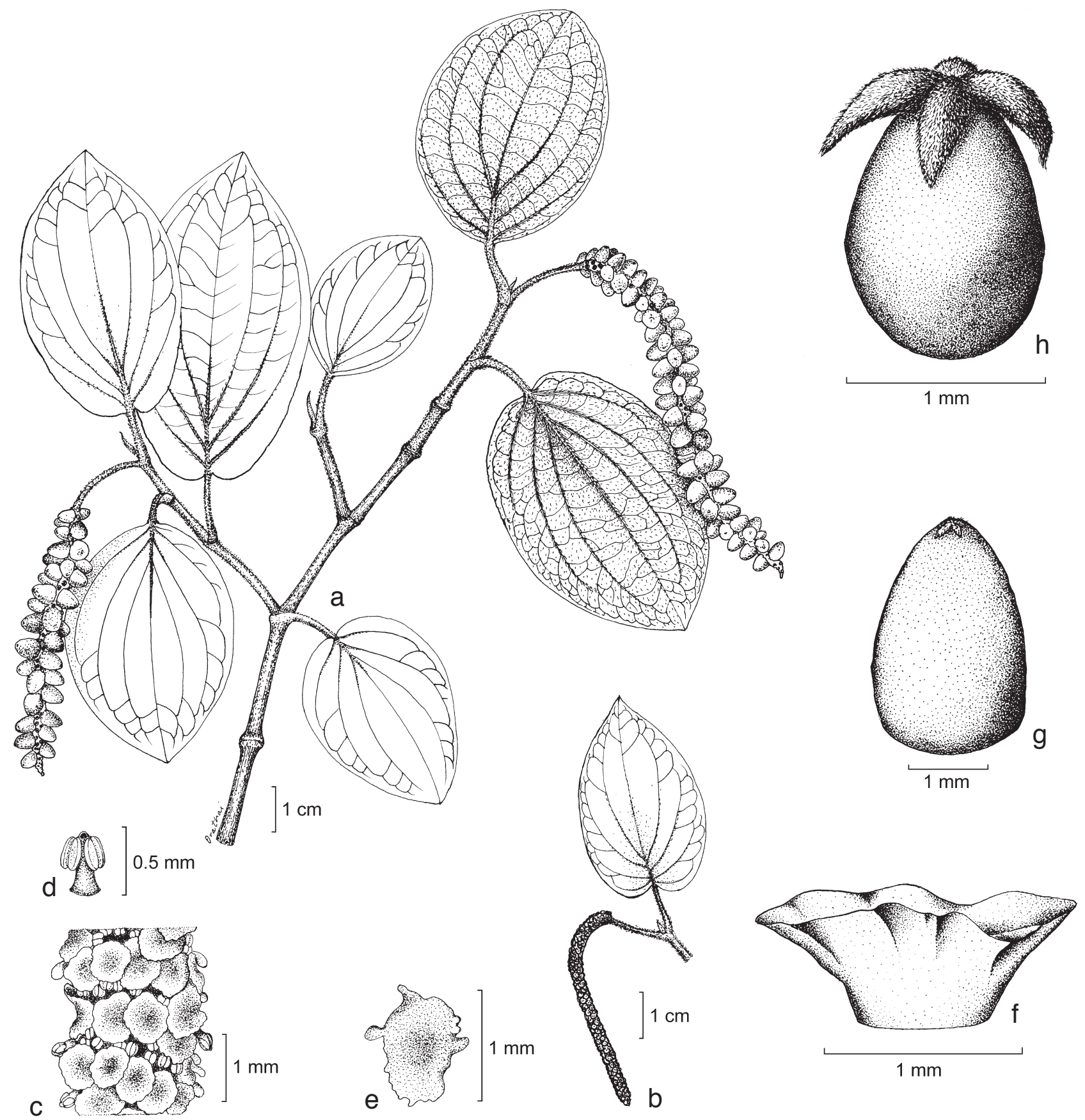

Fig. 3 Piper chiangdaoense Suwanp. \& Chantar. a. Branch with infructescences; b. male inflorescence; c. portion of male inflorescence; d. stamen; e, f. floral bract (top and side views); g. fruit; h. ovary with stigma (a: T. Smitinand et al. 7806 (BKF); b-f: S. Watthana 1266 (QBG)). - Drawn by Orathai Kerdkaew.

Table 2 Comparison of some characters of $P$. thomsonii and P. trichostigma.

\begin{tabular}{lll}
\hline Character & $P$. thomsonii & $P$. trichostigma \\
\hline Leaves & subcoriaceous & chartaceous \\
Male inflorescence & $2.3-5 \mathrm{~cm}$ long & $4-10 \mathrm{~cm}$ long \\
Floral bract & peltate or rounded & rounded \\
Fruit & connate c. $3 / 4$ & free \\
Fruit apex & acute & retuse \\
Mature fruit & dark purple or black & orange \\
Infructescence & shorter than peduncle & longer than peduncle \\
Infructescence size & $5-10$ by 5-12 mm & $2-6$ by $0.5-1 \mathrm{~cm}$ \\
Infructescence shape & subglobose & long cylindrical \\
Dried leaf & black & brown \\
\hline
\end{tabular}

Distribution - Thailand: Northern: Chiang Mai, Chiang Rai, Nan, Payao, Phrae, Tak; Central: Nakhon Nayok; South-western: Kanchanaburi, Phetchaburi; Peninsular: Chumphon, Phangnga. Habit \& Ecology — In evergreen forest by stream or waterfall.

Phenology - Flowering: March-April; fruiting: March-May.

Note - Because of the magnitude of the differences between this and $P$. thomsonii, some of which are listed in Table 2 , we raise $P$. thomsonii var. trichostigma to specific rank. In general the best characteristic for delimitation of the species is the infructescence but the type of $P$. trichostigma only contains a young inflorescence and no infructescence. Therefore, we select $C$. Suwanphakdee 259 as epitype because it has mature infructescences. 


\section{Piper argyrites Ridl.}

Piper argyrites Ridl. (1912) 25. — Type: Ridley 8176 (lecto SING; isolecto G-DC, here selected), Malaysia, Selangor, Gua Batucave, Dec. 1920.

Piper maculaphyllum Chaveer. \& Sudmoon (2008) 120. - Type: A. Chaveerach 126 (holo BK; iso BKF), Thailand, Phuket, Khao Phra Thaeo Wildlife Conservation Development and Extension Center, syn. nov.

Distribution - Malaysia, Singapore, Thailand (South-eastern and Peninsular).

Habitat \& Ecology - Growing near stream, along stream or evergreen hill forest.

Phenology - Flowering and fruiting: October-December.

Note — Of the two specimens cited by Ridley (1912) we were unable to find Ridley 7611 in K, G-DC or SING, and we choose Ridley 8176 as lectotype for Piper argyrites. Chaveerach et al. (2008) indicated that the type specimens of $P$. maculaphyllum were deposited in BK and BKF. However, we were unable to find these specimens and, from discussion with staff in BK and BKF, we understand that they were not actually deposited in these herbaria. We have examined the line drawing and description of $P$. maculaphyllum and found that features of leaves, inflorescence, floral bract, stamens and especially fruits and infructescence match with $P$. argyrites. Therefore, $P$. maculaphyllum is reduced to synonymy under $P$. argyrites. This species is widely distributed in South-eastern and Peninsular Thailand.

\section{Piper betle L.}

Piper betle L. (1753) 28. - Type: Herb. Hermann 3: 32; 4: 9, No. 27 (lecto BM, selected by Huber 1987), India.

Piper rubroglandulosum Chaveer. \& Mokkamul (Chaveerach et al. 2008) 142, (Chaveerach et al. 2010) 175. - Type: Chaveerach 314 (holo BK?; iso BKF?), Thailand, Surat Thani, Klong Panom National Park, syn. nov.

Distribution - India, Sri Lanka, China, Myanmar, Laos, Vietnam, Cambodia, Malaysia, Singapore, Thailand (Northern, South-eastern, Peninsular), Philippines, Indonesia, Papua New Guinea.

Habitat \& Ecology — In evergreen forest near stream, fruit plantation, disturbed area.

Phenology — Flowering: March-June; fruiting: May-July.

Note - Again, as with $P$. argyrites, we were unable to find the type of $P$. rubroglandulosum at BK and BKF as indicated by Chaveerach et al. (2008). We have carefully examined the description, line drawing and photographs of $P$. rubroglandulosum and found that it is a wild form of $P$. betle. Therefore, $P$. rubroglandulosum is reduced to synonymy of $P$. betle. Female plants of $P$. betle are cultivated throughout Thailand, but the wild form of both female and male plants can be found in nature only in south-eastern and southern regions.

Acknowledgements We would like to thank curators and staff of the following herbaria: BK, BKF, DMSC, G, G-DC, K, KKU, PSU, QBG and SING for permission to study the specimens and documents. We thank Orathai Kerdkaew (BKF) for the line drawing, Dr Piyakaset Suksathan (QBG), Manop Poopath for photos of $P$. chiangdaoense and Dr D.A. Simpson (K) for the Latin diagnosis and valuable suggestions. This project is financially supported by Graduate School, Khon Kaen University.

\section{REFERENCES}

Chaveerach A, Sudmoon R, Tanee T, Mokkamul P. 2008. The species diversity of the genus Piper L. from Thailand. Acta Phytotaxonomica et Geobotanica 59, 2: 105-163.

Chaveerach A, Sudmoon R, Tanee T, Mokkamul P. 2010. Notes on Piper rubroglandulosum (Piperaceae) in Thailand. Acta Phytotaxonomica et Geobotanica 60, 3: 175-177.

Chaveerach A, Tanomtong A, Sudmoon R, Tanee T, Mokkamul P. 2007. A new species and two new varieties of Piper (Piperaceae) from Thailand. Acta Phytotaxonomica et Geobotanica 58, 1: 33-38.

Huber H. 1987. Piperaceae. In: Dassanayake MD (ed), A revised handbook to the Flora of Ceylon: Vol. 6: 273-299. Amerind Publishing, New Delhi. Linnaeus C. 1753. Species Plantarum. Vol. 1. London

Mabberley DJ. 2008. Mabberley's plant-book, A portable dictionary of plants, their classification and uses. 3rd edition, Cambridge University Press.

Office of Forest Herbarium, Department of National Parks, Wildlife and Plant Conservation. 2010. http://web3.dnp.go.th/botany/Botany_Eng/FloraofThailand/flora_Eng_treated.html. Last accessed 29 October 2010.

Ridley HN. 1912. Piperaceae Novae E Peninsula Malayana. In: De Candolle C (ed), Records Botanical Survey of India. Vol. 6, 1: 25. Calcutta Superintendent. Government Printing, India.

Yuncker TG. 1958. The Piperaceae: a family profile. Brittonia 10: 1-7.

\section{IDENTIFICATION LIST}

$$
\begin{array}{ll}
\text { Piper } & \\
1=\text { argyrites } & 4=\text { lonchites } \\
2=\text { betle } & 5=\text { thomsonii } \\
3=\text { chiangdaoense } & 6=\text { trichostigma }
\end{array}
$$

Adisai 48: 6 - Anderson 5258: 2

Bloembergen 619: 6 - Bunwong 199: 4.

Chamchamroon et al. 1484: 6 - Chaveerach 49: 6 (type) - Chayamarit 1326: 6 .

Geesink \& T. Santisuk 5195: 6 - Geesink et al. 5703: 6; 6715: 1; 6878: 4. Hooker \& Thomson 181: 5 (type).

Kerr 4741: 4; 5654: 4; 5759: 4; 6221: 4; 8451: 4; 11806: 2; 12207: 2 ; 13793: 2 - Konta et al. 4751: 4 - Kostermans 351: 6; 351a: 6 - Koyama T-61908: 4; T-61136: 4 - Koyama \& C. Phengklai T-49903: 4 - Koyama et al. T-31828: 4

Larsen \& S.S. Larsen 33211: 2; 33927: 4 - Larsen et al. 3053: 6; 43153: 6; $46521: 4$.

Maxwell 88-693: 4; 88-987: 4; 89-428: 6; 93-841: 4; 93-1115: 4; 95-53: 4; 95-498: 6; 95-841: 4; 95-1215: 4; 96-849: 4; 99-70: 4 - Middleton et al. 1644: 6 - Mitsuta et al. T-43155: 4. Nagamasu T-50068: 4 - Nakkan 2: 4 - Nanakorn et al. 2597: 4; 4722: 4; 9175: 4.

Palee 253: 4 - Phengklai 1272: 1; 7075: 4; 7477: 4 - Phengklai et al. 2940: 6; 4107: 4 - Pongamornkul 1910: 4 - Pooma 621: 4 - Put 1034: 2; 3394: 4. Ridley 8176: 1 (type).

Sangkhachand 1450: 6 - Santisuk 1065: 4 - Santisuk \& E. Warncke 2554: 6 - Shimizu T-10048: 4 - Shimizu et al. T-10948: 3; T-23682: 4 - Smitinand 5471: 4; 6007: 6; 7806: 4; 11544: 4 - Smitinand et al. 7806: 3 (type) - Srisanga 1699: 6 - Srisanga \& C. Maknoi 2188: 4 - Suvarnakoses 1155: 6 ; 2173: 2 - Suwanphakdee 4: 6; 13: 2; 31: 6; 44: 2; 59: 4; 66: 4; 68: 2; 79: 4; 84: 4; 91: 4; 94: 6; 97: 4; 103: 2; 123: 6; 129: 6; 130: 6; 131: 4; 132: 2; 145: 4; 152: 6; 157: 4; 158: 4; 163: 6; 164: 4; 165: 6; 167: 1; 170: 2; 172/1: 1 ; 173: 4 ; 245: 1 ; 246: 1 ; 247: 1 ; 254: 4; 259: 6 (epitype); 260: 4; 268: 2 ; 274 : 6; 276: 4; 286: 1; 290: 4; 292: 4; 293: 6; 311: 4; 313: 2; 314: 2; 317: 1.

Tagawa et al. T-1536: 4; T-9158: 4 -Takahashi T-63531: 4 -Tanaka 8146: 4. Van Beusekom \& C. Phengklai 136: 6; 250: 6; 1359: 3; 2444: 4 - Van Beusekom \& T. Smitinand 2151: 4 - Van Beusekom et al. 4516: 4 - Van de Bult 621: 6 - Vidal et al. 6181: 4.

Watthana 1266: 3; 2428: 4 - Watthana et al. 605: 4 - Williams et al. 1108: 4; $1221: 6$. 